\title{
Is Effective Education in the Hands of Private Schools or Government? Comparative Analysis Between Government and Private Sector
}

\author{
Dr. Mukhtar Ahmed, Ph.D \\ Regional Director (Gujranwala), \\ Allama Iqbal Open University, Islamabad \\ rd_gujranwala@aiou.edu.pk \\ Tariq Mahmood \\ PhD Research Fellow \\ University of Education, Division of Education \\ College road Town ship, Lahore, Pakistan \\ Corresponding author: +923014981592 \\ tariq903@hotmail.com
}

\section{Muhammad Amin Ghuman}

PhD Scholar, International Islamic University Islamabad Senior Subject Specialist GHSS Eminabad (Gujranwala)

Sajida Parveen

M. Phil scholar University of Education, Division of Education

\section{Doi:10.5901/jesr.2013.v3n2p359}

\section{Abstract}

In Pakistan there is growing trend of private education system. Formal and in formal discussions showed that this trend is due to the use of English language teaching and English language as the medium of instruction in private sector. Therefore, it is felt to diagnose the situation in its real sense. The main purposes of the study were: (i) to see the use of resources both in public and private schools. (ii) to diagnose the use of teaching techniques while teaching of English in public and private sector. The study was conducted on a sample 1440 students which were selected from the Punjab province through multi-stage sampling technique. The collected data was analyzed by using SPSS software. Main findings of the study were: Use of A.V. Aids is more frequent in public schools than private schools. Attitude of teachers with students in private school is better than public school teachers. Majority of the public sector school teachers do not encourage students to read English news paper. Majority of the public sector schools rarely or never arrange speech competitions among students while private schools arrange such competitions. Majority of public school teachers rarely or never explain English concept in English but they explain in Urdu.

\section{Introduction}

Education can be seen as a product or a process and considered in a broad sense or a technical sense according to Kneller (1971). In its broader sense, the term education refers to any act or experience that has a formative effect on the mind, character, or physical ability of an individual. In its technical sense education is the process by which society, through schools, colleges, universities, and other institutions, deliberately transmits its cultural heritage, knowledge, values, and skills from one generation to another generation. 
It is also accepted that assessment, curriculum and pedagogy are closely interlinked (Black, 2006). Teacher is the main pillar in every education system. Because teaching can be done in different ways but teacher should be there to perform any process of learning.

A number of terms such as the practice teaching, student teaching, teaching practice, field studies, infield experience, school based experience or internship are used to refer to this activity (Taneja, 2000). The term practice teaching embraces all the learning experiences of student teachers in schools (Ashraf, 1999). The proposal that adopting uniform standards for teaching and learning will automatically result in academic success is challenged by an inclusive discourse of difference that reviews formal education as perpetuating pedagogical practices (Gale \& Densmore, 2000).

Teachers need to understand a subject enough to convey its essence to students. The goal is to establish a sound knowledge base on which students will be able to build as they are exposed to different life experiences. The passing of knowledge from generation to generation allows students to grow into useful members of society.

The structure of education system all over the world is same with little bit variations. According to the National Education Policy (1998-2010), the education system of Pakistan is three tier: elementary (grade 1-8); secondary (grade 9-12); and higher education (grade 13 and above).

Today each region of Pakistan, at various levels, operates in three and sometimes in four languages. First each region has its own regional language as language of every day communication; then Urdu as the language of instructions in official schools and English as language of official business and language of instruction in the private schools; and finally Arabic as language of learning and performing Islamic religious rituals. One would imagine that after sixty years of official patronage of Urdu and English all Pakistanis, regardless of their own regional language, would be able to communicate with each other freely in one or two languages.

It is almost universal truth that isolation from social, economic, political and educational sphere is impossible. This slogan is becoming more prominent in the present era of technology and globalization. As the whole world is shirking in a global village, so the communication needs at international level are increasing rapidly. Hence the learning of languages other than mother tongue are becoming necessary day by day. Presently, English is considered as international language because more than half of the world can speak and understand English language. So the teaching learning process should be efficient for complete understanding. Because if there is learning among students then we can say that there is teaching process as well. Am I teaching, for instance, if you are learning nothing (Barrow \& Woods, 2006).

There are two views about the use of English language. One is "English language teaching" and second is "English as the language of instruction". Majority of the people misunderstand between these two concepts. For example, studies showed that most of the parents have the view that mother tongue is more effective medium of instruction for understanding than English language. But still parents preferred English language as the medium of instruction for their children. Parents support their preference by saying that English is international language and necessary to get good employment.

A lot of Pakistani students cannot follow English language properly in their classes; as a result most of them fail in English language examinations. Teachers need to update their standards by not only reading the text from the book in front of students but by explaining their text with some common examples at the student's level. They should give full confidence to students to ask, share their difficulties and insist students speak English language during the class no matter how much they know about the English. There are many methods of teaching languages. Some have fallen into relative obscurity and others are widely used; still others have a small following, but offer useful insights. Learning strategies are the techniques that students use to understand and retain information and to solve problems (Ovando, Collier \& Combs, 2003).

It is the language of the world in all fields of the art, hard sciences, humanities and social sciences. International trade, commerce and diplomacy are conducted in English language almost all over the world. Even the developing countries also use English language as official language. In Pakistan English is taught and learn as a second language to the national language Urdu. English is also used as an official language in our offices because $80 \%$ correspondence is done in English language. All over the world it is being accepted that if English language is is neglected, there will be destruction of many fields like education, commerce and technology. English is important and necessary for the development of Pakistan but the achievement level is very low in 
Pakistani institutions. There is fast decline of English language in Pakistani students, they also lack of sentence making (Khamisani, 1983).

In 1984 Govt. of Pakistan allowed the community to open their own privately managed schools. In 1985 government announced that the government alone could not carry the burden of whole education system. It was therefore considered necessary to encourage the community participation in educational development and announced to return the educational institutions to the previous administration under some provisions. As a result of this announcement a few institutions were denationalized because other refused to accept the government provisions. In 1992 government announced incentives to open private schools. At this time a large number of schools are running under the private management and NGOs parallel to the government and nationalized schools. All these steps to provincilize, nationalize, de-nationalize and under the supervision of NGO's have been taken to improve the quality of education and enhance the literacy rate in Pakistan.

In Pakistan the medium of instruction at school and college level is Urdu but student has the choice to opt Urdu or English language in examination. English as a subject is compulsory for all students from grade VI to graduate level. But the governments of Punjab and Sindh have decided English as a compulsory subject from class one in almost 1993. On the other side government has taken steps to control the private sector of education. But according to Education Policy 2009, existence of insulated public and private education in Pakistan remains a cause for concern as it creates inequitable social divides. It is further explained that there are two basic reasons for this are high fees to attract elite class and unequal curricula at different classes.

From different researches and informal observations it is clear that recently the trend of private education is increasing rapidly in comparison to previous years. What is the reason behind this phenomenon is a very crucial question. It is also observed that this trend is due to the use of English language teaching and English language as the medium of instruction in private sector. Therefore, it is felt to diagnose the situation in its real sense. There are so many ways to diagnose the activities done for the teaching of English. One notable feature of educational research is the variety of it. Different approaches are used to answer different questions. That, of course, makes sense where that which is being researched into, namely, educational practice, is a complex phenomenon. Different sorts of question require different sorts of research (Pring, 2004). So a survey study has been designed to see the practices done in public and private sector for the teaching of English.

\section{The study will be Significant:}

In the present era there are two views about the world, on the one side it is said that there are two types of countries-developed countries and developing countries. On the other side due to fast communication process it is said that the world where we are living is just like a global village. So the inhabitants of this world will communicate with one another in some similar language. At the present time it is accepted that English is international language. The future of every nation is the students who are studying at various levels. In the same way the students of our schools are the future of Pakistan. So they are taught a language which is necessary for communication at national as well as at international level. Both the public and private sector of education in Pakistan are teaching English as compulsory subject. Teaching of language particularly English language is a very tough job. Teaching of English requires so many diverse and innovative practices. Private education systems are saying that they are providing good opportunities of learning English, while on the other side, Ministry of Education through its Policies and Plans are providing high standard benchmarks of teaching and learning of English. The results of this study will greatly facilitate its stakeholders (students and parents) about the selection of public or private sector to learn English language effectively. The other stakeholders (teachers, headmasters and policymakers) will also find some good teaching practices from the results of this study to improve the infrastructure for effective teaching learning of English language.

Data collected from teachers about their performance in the context of English teaching practices in public and private schools in the province of Punjab was analyzed and interpreted as under: teachers were asked about the good practices which were done by them in their institutions. Then according to their views following comparison of public and private schools was done which is shown in the following tables. 


\begin{tabular}{|c|c|c|c|c|c|c|c|}
\hline \multirow[b]{2}{*}{$\mathrm{Sr} \#$} & \multirow[b]{2}{*}{ Statement } & \multicolumn{2}{|l|}{ Agree } & \multicolumn{2}{|c|}{ Disagree } & \multicolumn{2}{|c|}{ Undecided } \\
\hline & & Public & Private & Public & Private & Public & Private \\
\hline 1 & Preparation of lesson & $12,9 \%$ & $90.0 \%$ & $60.0 \%$ & $5,7 \%$ & $27,1 \%$ & $4,3 \%$ \\
\hline 2 & Student's participation & $38,5 \%$ & $87,1 \%$ & $52,9 \%$ & $10.0 \%$ & $8,6 \%$ & $2,9 \%$ \\
\hline 3 & Provide extra material & $40.0 \%$ & $92,9 \%$ & $57,1 \%$ & $5,7 \%$ & $2,9 \%$ & $1,4 \%$ \\
\hline 4 & Instant verbal feedback & $42,9 \%$ & $70.0 \%$ & $48,6 \%$ & $15,7 \%$ & $8,6 \%$ & $14,3 \%$ \\
\hline 5 & Instant written feedback & $20.0 \%$ & $84,3 \%$ & $75,7 \%$ & $10.0 \%$ & $4,3 \%$ & $5,7 \%$ \\
\hline 6 & Good pupil-teachers interaction & $67,1 \%$ & $92,9 \%$ & $24,3 \%$ & $5,7 \%$ & $8,6 \%$ & $1,4 \%$ \\
\hline 7 & Use of teaching aids in lesson & $78,6 \%$ & $27,1 \%$ & $11,4 \%$ & $60.0 \%$ & $10.0 \%$ & $12,9 \%$ \\
\hline 8 & Use of lecture method teaching & $75,7 \%$ & $10.0 \%$ & $18,6 \%$ & $82,9 \%$ & $5,7 \%$ & $7,1 \%$ \\
\hline 9 & Students interest in English & $24,3 \%$ & $90.0 \%$ & $62,9 \%$ & $1,4 \%$ & $12,9 \%$ & $8,6 \%$ \\
\hline 10 & $\begin{array}{l}\text { Teaching of English is good } \\
\text { experience }\end{array}$ & $20.0 \%$ & $85,7 \%$ & $70.0 \%$ & $8,6 \%$ & $10.0 \%$ & $5,7 \%$ \\
\hline
\end{tabular}

Teachers were asked either they prepare their lesson before going to classroom. $90 \%$ teachers from private sector prepare their lessons before going to classroom while only $12 \%$ teachers from public sector schools prepare their lessons. When they were asked about the involvement of students in lesson, they responses showed that $87 \%$ teachers in private school and only $38 \%$ of public school teachers involve students in lesson or lecture. Students' involvement increases the understanding level of students. 92\% private school teachers extra material to students for more clarity of the concept and only $40 \%$ teachers of public schools provide extra material to students. Teachers of private schools provide verbal as well as written feedback to students $70 \%$ and $84 \%$ respectively, while only $42 \%$ teachers of public school provide verbal feedback and $20 \%$ teachers provide written feedback. Student-teacher interaction in private school is better with $92 \%$ and in public school is lower with $67 \%$. But the teachers of public schools use more A.V.Aids than private school teachers with $78 \%$ and $27 \%$ respectively. Teachers of public schools use lecture method as teaching method with a high percentage of $75 \%$, while teachers of private schools does not only focus on lecture method. Private school students show more interest in the learning of English than public school students. $90 \%$ students of private sector showed more interest in the learning of English, on the other hand only $27 \%$ students of public schools showed interest. In the answer of another question 85\% teachers replied that teaching of English is a good experience while only $20 \%$ teachers of public schools replied in this regard.

\begin{tabular}{|c|c|c|c|c|c|c|c|}
\hline \multirow[b]{2}{*}{ Sr \# } & \multirow[b]{2}{*}{ Statement } & \multicolumn{2}{|l|}{ Agree } & \multicolumn{2}{|c|}{ Disagree } & \multicolumn{2}{|c|}{ Undecided } \\
\hline & & Public & Private & Public & Private & Public & Private \\
\hline 11 & Students cooperate with others & $51,4 \%$ & $44,3 \%$ & $35,7 \%$ & $41,4 \%$ & $12,9 \%$ & $14,3 \%$ \\
\hline 12 & Teaching of English is boring & $25,7 \%$ & $75,8 \%$ & $68,6 \%$ & $15,7 \%$ & $5,7 \%$ & $8,6 \%$ \\
\hline 13 & Use black board while teaching & $74,3 \%$ & $11,4 \%$ & $20.0 \%$ & $84,3 \%$ & $5,7 \%$ & $4,3 \%$ \\
\hline 14 & Students satisfied with teaching & $97,3 \%$ & $84,3 \%$ & $0.0 \%$ & $10.0 \%$ & $2,9 \%$ & $5,7 \%$ \\
\hline 15 & $\begin{array}{l}\text { Curriculum is: good for speaking } \\
\text { ability }\end{array}$ & $14,3 \%$ & $42,9 \%$ & $80.0 \%$ & $47,1 \%$ & $5,7 \%$ & $10.0 \%$ \\
\hline 16 & Good for listening ability & $2,9 \%$ & $10.0 \%$ & $88,6 \%$ & $60.0 \%$ & $8,6 \%$ & $30.0 \%$ \\
\hline 17 & Good for writing ability & $44,3 \%$ & $70.0 \%$ & $48,6 \%$ & $24,3 \%$ & $7,1 \%$ & $5,7 \%$ \\
\hline 18 & Good for reading ability & $51,4 \%$ & $82,8 \%$ & $42,9 \%$ & $14,3 \%$ & $5,7 \%$ & $2,9 \%$ \\
\hline 19 & Curri is fit for needs of students & $21,4 \%$ & $20.0 \%$ & $72,9 \%$ & $74,3 \%$ & $5,7 \%$ & $5,7 \%$ \\
\hline 20 & Curri is interesting for students & $64,3 \%$ & $80.0 \%$ & $28,6 \%$ & $14,3 \%$ & $7,1 \%$ & $5,7 \%$ \\
\hline
\end{tabular}

Student's cooperation with one another is a basic thing for healthy teaching learning environment of any institution. According to the data collected by teachers $44 \%$ students of private schools cooperate with one another, while $51 \%$ students of public schools cooperate friendly. $75 \%$ teachers of private school feel boredom in teaching of English while only $25 \%$ teachers of public schools feel boring. $74 \%$ teacher of public schools use black board while teaching of English, while only 25\% teachers use black board for the teaching of English and rest of the private school teachers use other boards i.e. white board etc. Both the school system students are 
satisfied with the teaching methods used by their teachers with high percentages (public $97 \%$ and private $84 \%$ ). When the teachers were asked about the effectiveness of curriculum both the sector said that curriculum is not appropriate for the development of speaking ability, listening ability and writing ability but for the development of reading ability this is appropriate according to public school teachers and private school teachers with $51 \%$ and $82 \%$ respectively. Teachers of both sectors were also of the view that curriculum is not fit for the needs of students because $72 \%$ of public school teachers were of the view that curriculum is not appropriate and $74 \%$ of private school teachers have the same view. But when they were asked that either curriculum is interesting for students or not, majority of the teachers from both sectors were of the view that curriculum is interesting for students.

\begin{tabular}{|c|c|c|c|c|c|c|c|}
\hline \multirow[b]{2}{*}{ Sr \# } & \multirow[b]{2}{*}{ Statement } & \multicolumn{2}{|l|}{ Agree } & \multicolumn{2}{|c|}{ Disagree } & \multicolumn{2}{|c|}{ Undecided } \\
\hline & & Public & Private & Public & Private & Public & Private \\
\hline 21 & Curri is interesting for teachers & $20.0 \%$ & $80.0 \%$ & $74,3 \%$ & $15,7 \%$ & $5,7 \%$ & $4,3 \%$ \\
\hline 22 & Give class work during lesson & $8,6 \%$ & $75,7 \%$ & $74,3 \%$ & $12,9 \%$ & $17,1 \%$ & $11,4 \%$ \\
\hline 23 & Give home work regularly & $74,3 \%$ & $8,6 \%$ & $14,3 \%$ & $84,3 \%$ & $11,4 \%$ & $7,1 \%$ \\
\hline 24 & Complete syllabus in time & $24,3 \%$ & $65,7 \%$ & $71,4 \%$ & $31,4 \%$ & $4,3 \%$ & $2,9 \%$ \\
\hline 25 & Student center teaching method & $77,2 \%$ & $18,6 \%$ & $8,6 \%$ & $75,7 \%$ & $14,3 \%$ & $5,7 \%$ \\
\hline 26 & Encourage students for question & $64,3 \%$ & $87,2 \%$ & $31,4 \%$ & $1,4 \%$ & $4,3 \%$ & $11,4 \%$ \\
\hline 27 & Good student-teacher relation & $77,1 \%$ & $40.0 \%$ & $20.0 \%$ & $52,9 \%$ & $2,9 \%$ & $7,1 \%$ \\
\hline 28 & Focus on individual difference & $12.9 \%$ & $38,6 \%$ & $81,4 \%$ & $52,9 \%$ & $5,7 \%$ & $8,6 \%$ \\
\hline 29 & Boredom on mistakes & $14,3 \%$ & $10.0 \%$ & $78,6 \%$ & $85,7 \%$ & $7,1 \%$ & $4,3 \%$ \\
\hline 30 & Good attitude toward teaching & $51,4 \%$ & $78,6 \%$ & $40.0 \%$ & $8,6 \%$ & $8,6 \%$ & $12,9 \%$ \\
\hline
\end{tabular}

$80 \%$ teachers of private schools were of the view that curriculum is also interesting for teachers and only $70 \%$ teachers were agree with the above statement. Class work is more suitable for students than home work because students done their class work under the proper guidance of teacher. $75 \%$ private school teachers give students class work instead of home work, while $74 \%$ teachers of public schools give home work instead of class work. $65 \%$ private school teachers finish their syllabus in the given time, while only $24 \%$ teachers of public schools finish syllabus in time. $77 \%$ teachers of public schools and $18 \%$ teachers of private schools use student centered teaching method. $87 \%$ teachers of private school teachers and $64 \%$ public school teachers encourage their students to ask questions. Students' participation in the teaching learning process increases the understanding level of students. $77 \%$ teachers of public schools were of the view that there exists good studentteacher relationship, on the other hand, only $40 \%$ teachers were agree that good relationship exist. In the present era students belong from different backgrounds and different families so teaching according to individual differences is more effective than any other way. But only $12 \%$ of public school teachers and $38 \%$ of private school teachers teach to students according to there individual differences. $78 \%$ teachers of public schools and $85 \%$ teachers of private schools said that they did not feel boredom on continuous mistakes of students. $51 \%$ public school teachers and $78 \%$ private school teachers have good attitude towards the teaching of English.

\begin{tabular}{|c|c|c|c|c|c|c|c|}
\hline \multirow[b]{2}{*}{ Sr \# } & \multirow[b]{2}{*}{ Statement } & \multicolumn{2}{|l|}{ Agree } & \multicolumn{2}{|c|}{ Disagree } & \multicolumn{2}{|c|}{ Undecided } \\
\hline & & Public & Private & Public & Private & Public & Private \\
\hline 31 & Cooperative behavior & $75,7 \%$ & $48,6 \%$ & $20.0 \%$ & $22,9 \%$ & $4,3 \%$ & $8,6 \%$ \\
\hline 32 & New ways of class sessions & $27,1 \%$ & $71,4 \%$ & $68,6 \%$ & $20.0 \%$ & $4,3 \%$ & $8,6 \%$ \\
\hline 33 & Peer learning technique & $18,5 \%$ & $50.0 \%$ & $80.0 \%$ & $44,3 \%$ & $1,4 \%$ & $5,7 \%$ \\
\hline 34 & Group work of students & $24,3 \%$ & $64,3 \%$ & $74,3 \%$ & $30.0 \%$ & $1,4 \%$ & $5,7 \%$ \\
\hline 35 & Arrange oral quizzes & $10.0 \%$ & $48,6 \%$ & $87,1 \%$ & $48,6 \%$ & $2,9 \%$ & $2,9 \%$ \\
\hline 36 & Teach vocabulary practically & $31,4 \%$ & $87,2 \%$ & $64,3 \%$ & $2,9 \%$ & $4,3 \%$ & $10.0 \%$ \\
\hline 37 & Teacher training is necessary & $37,1 \%$ & $80.0 \%$ & $62,9 \%$ & $15,7 \%$ & $0.0 \%$ & $4,3 \%$ \\
\hline 38 & Feel uncomfortable in teaching & $60.0 \%$ & $5,7 \%$ & $34,3 \%$ & $90.0 \%$ & $5,7 \%$ & $4,3 \%$ \\
\hline 39 & $\begin{array}{l}\text { Feel problems in checking home } \\
\text { works }\end{array}$ & $71,4 \%$ & $1,4 \%$ & $21,4 \%$ & $85,7 \%$ & $7,1 \%$ & $12,9 \%$ \\
\hline 40 & Need tuition with lecture also & $51,4 \%$ & $10.0 \%$ & $38,6 \%$ & $81,4 \%$ & $10.0 \%$ & $8,6 \%$ \\
\hline
\end{tabular}


Teachers' behavior towards students is also very much important for effective learning. 75\% of public school teachers have cooperative behavior with students, while $48 \%$ private school teachers cooperate friendly. $71 \%$ Private school teachers arrange their class sessions in new and innovative ways, while only $27 \%$ teachers from public schools arrange their session in new ways. Peer learning is also a good technique fro better understanding of the lesson. Only $18 \%$ of public school teachers and $50 \%$ of private school teachers use peer learning technique for more clarity of the concept. $64 \%$ of private and $24 \%$ of public school teachers assign students group work. Oral quizzes are also beneficial for students learning. $10 \%$ of public school teachers and $48 \%$ private school teachers arrange oral quizzes for students. $31 \%$ public school teachers and $87 \%$ private school teachers teach vocabulary to students in practical form. $37 \%$ teachers of public school teachers and $80 \%$ of private school teachers said that teacher training is necessary for effective teaching learning process. $60 \%$ teachers of public schools and only $5 \%$ teachers of private schools feel uncomfortable in teaching of English. $71 \%$ of public school teachers and only $1 \%$ teachers from private schools feel problems in checking home work. $51 \%$ of public school teachers said that tuition other than lecture is also necessary, while $10 \%$ of private school teachers were of the same view.

\begin{tabular}{|c|c|c|c|c|c|c|c|}
\hline \multirow[b]{2}{*}{ Sr \# } & \multirow[b]{2}{*}{ Statement } & \multicolumn{2}{|l|}{ Agree } & \multicolumn{2}{|c|}{ Disagree } & \multicolumn{2}{|c|}{ Undecided } \\
\hline & & Public & Private & Public & Private & Public & Private \\
\hline 41 & Need professional enhancement & $65,7 \%$ & $42,8 \%$ & $12,9 \%$ & $50.0 \%$ & $21,4 \%$ & $7,1 \%$ \\
\hline 42 & Charts/models are present & $42,8 \%$ & $80.0 \%$ & $48,6 \%$ & $12,9 \%$ & $8,6 \%$ & $7,1 \%$ \\
\hline 43 & White board is present & $31,4 \%$ & $70.0 \%$ & $64,3 \%$ & $15,7 \%$ & $4,3 \%$ & $14,3 \%$ \\
\hline 44 & Have multimedia in institution & $12,8 \%$ & $61,5 \%$ & $87,1 \%$ & $37,1 \%$ & $0.0 \%$ & $1,4 \%$ \\
\hline 45 & Show English films & $8,6 \%$ & $22,9 \%$ & $81,4 \%$ & $61,4 \%$ & $10.0 \%$ & $15,7 \%$ \\
\hline 46 & Read English news paper daily & $5,8 \%$ & $77,2 \%$ & $91,4 \%$ & $17,1 \%$ & $2,9 \%$ & $5,7 \%$ \\
\hline 47 & Teach vocabulary with pictures & $4,3 \%$ & $38,6 \%$ & $95,7 \%$ & $47,1 \%$ & $0.0 \%$ & $14,3 \%$ \\
\hline 48 & Provide hand books to students & $20.0 \%$ & $72,9 \%$ & $75,7 \%$ & $20.0 \%$ & $4,3 \%$ & $7,1 \%$ \\
\hline
\end{tabular}

Teachers were asked about their professional enhancement. $65 \%$ of public school teachers and $42 \%$ of private school teachers were of the view that they need more professional development for the betterment of teaching learning process. $42 \%$ of public schools and $80 \%$ private school teachers have charts and models in their schools and classrooms. Only 30\% teachers from public schools said that they have white board in their classrooms and $70 \%$ of private school teachers have white board in their classrooms. In the present modern era multimedia is a very suitable A.V. Aid to enhance teaching process. $12 \%$ public schools and $61 \%$ private schools have multimedia for class lectures. Teaching of English ascent by showing them English films is a very good technique. $8 \%$ public schools and $22 \%$ private schools show their students English films to teach them ascent of English language. 77\% students in private schools daily read English news paper, while in public schools only 5\% students read English news paper. 4\% public school teachers and 38\% private school teachers show pictures to students of those words which they taught to students. $20 \%$ teachers in public schools and $72 \%$ of private school teachers provide hand books to students.

Main findings and conclusions of the study are as under:

$>$ Majority of the private school teachers prepare their lesson before going to classroom and also involve students in lesson or lecture.

$>$ Most of the private school teachers provide extra material to students for more clarity of the concept.

$>$ Most of the private school teachers provide verbal as well as written feedback to students, while public schools lack in this regard.

$>$ Student-teacher interaction in private school is better than in public school.

$>\quad$ Use of A.V. Aids is more frequent in public schools than private schools.

$>$ Teachers of public schools use lecture method as teaching method.

$>$ Majority of the private school teachers and students showed interest in the teaching and learning of English.

$>\quad$ Majority of the public school teachers use black board during the teaching of English, while majority of the private school teachers use white board in the teaching of English.

$>$ Both the school systems were of the view that curriculum is also interesting for teachers. 


\section{Recommendations:}

Following are the future recommendations of this study:

$>$ Professional development courses should be arranged for teachers of public schools as well as private schools.

$>$ An in depth study is also necessary for the proper diagnoses of actual situation.

$>$ Proper check and balance system should be arranged to enhance the English language achievement in public schools.

> Public schools should be provided with innovative A.V. Aids (such as language lab) for the proper teaching and learning of English language.

$>$ Curriculum of both public and private schools should be upgraded to develop all the four skills in students.

\section{References}

Ashraf, M. (1999). Dictionary of Primary Education. New Delhi: A.P.H. Publishing Corporation.

Barrow, R. \& Woods, R. (2006). An introduction to philosophy of education, $4^{\text {th }}$ Edition, New York: Routledge taylor \& Francis Group.

Black, P. (2006). Teaching purpose into practice in science education. In Woods-Robinson, V. (Ed.), ASE Guide to Secondary Science Education. Hatfield: Association for Science Education.

Gale, T. and Densmore, K. (2000). Just Schooling: Explorations in the Cultural Politics of Teaching. Buckingham: Open University Press.

Government of Pakistan, Ministry of Education, National Education Policy, 1998-2010, Islamabad

Khamisani, A. (1983). The role of English ion Pakistan. English Language Teaching. Islamabad: University Grants Commission.

Kneller, G. F. (1971). Introduction to the Philosophy of Education. New York: John Wiley and Sons.

Ovando, C. J., Collier, V. P., \& Combs, M. C. (2003). Bilingualism \& ESL Classroom: Teaching in Multicultural Contexts. (3 ${ }^{\text {rd }}$ Ed.) Boston: Mc Graw Hill.

Pring, R. (2004). Philosophy of Educational Research. $2^{\text {nd }}$ Edition. New York: Continuum.

Taneja, R. P. (2000). Encyclopedia of Comparative Education, Vol.4. New Delhi: Anmol Publications Pvt. Ltd. 
